\section{Influence of Root Canal Filling Techniques on Sealer Penetration and Bond Strength to Dentin}

Luciana Martins Domingues de Macedo, Yara Silva-Sousa1, Silvio Rocha Corrêa da Silva' ${ }^{1}$, Samantha Schaffer Pugsley Baratto ${ }^{2}$, Flares Baratto-Filho ${ }^{2}$, Fuad Jacob Abi Rached-Júnior ${ }^{1}$
'School of Dentistry, UNAERP Universidade de Ribeirão Preto, Ribeirão Preto, SP, Brazil ${ }^{2} \mathrm{School}$ of Dentistry, UP - Universidade Positivo, Curitiba, PR, Brazil

Correspondence: Dr. Fuad Jacob Abi Rached-Júnior. Rua Florêncio do Rosário 260, Bosque dos Juritis, 14021-675 Ribeirão Preto, SP, Brasil. Tel: +55-16-3441-2458. e-mail: rached-junior@hotmail.com

\begin{abstract}
The influence of root canal filling techniques on the penetration of AH Plus into dentinal tubules was evaluated using confocal laser scanning microscopy (CLSM) and the impact on the bond strength of the filling material on the root dentin was evaluated using the push-out test. Roots of the maxillary central incisors $(n=40)$ were prepared with ProTaper Universal and assigned to four groups: lateral condensation, vertical compaction, modified Tagger hybrid and single cone. After root canal filling with gutta-percha and AH Plus, along with the addition of $0.01 \%$ fluorescein, the roots were cut into $2-\mathrm{mm}$ slices. CLSM was performed on the first slice of each root third, followed by the push-out test. The second slice was analyzed under SEM. ANOVA demonstrated a statistically significant difference between the root canal filling techniques and the root thirds $(p<0.05)$. For percent penetration, Tukey's test showed that the vertical compaction $(91.77 \pm 13.51)$, lateral condensation $(89.18 \pm 10.91)$ and modified Tagger hybrid $(87.53 \pm 15.42)$ presented the highest values, which significantly differed $(p<0.05)$ from those of the single cone $(78.19 \pm 22.46)$. For bond strength $(\mathrm{MPa})$, lateral condensation $(3.42 \pm 0.54)$ and vertical compaction $(3.47 \pm 0.53)$ had the highest values $(p<0.05)$, while the modified Tagger hybrid $(2.19 \pm 0.41)$ and single cone $(0.54 \pm 0.21)$ had the lowest. In conclusion, the lateral condensation, vertical compaction and Modified Tagger's hybrid techniques resulted in greater penetration and bond strength to the intra-radicular dentin.
\end{abstract}

Key Words: endodontics, confocal laser scanning microscopy, bond strength.

\section{Introduction}

The penetration of endodontic sealers into dentinal tubules and bond strength to the dentin is directly associated with the removal of smear layers $(1,2)$, physical and chemical properties of the sealer (3) and root canal filling technique (4).

Different root canal filling techniques have been proposed $(5,6)$ as attempt to fill the root canal in three dimensions (7) and reduce marginal apical and coronal infiltration (8). Among these techniques, lateral condensation, which is the most commonly used technique, is worth mentioning (7) and warm vertical compaction, which promotes plastification of gutta-percha to provide homogeneity of the obturating mass and better adaptation to the root canal walls (9).

With technological advances in endodontic instruments in the last years, the single-cone sealing technique has been also widely used. Its advantages are: it adapts to the final diameter achieved by biomechanical preparation, it allows for a greater amount of gutta-percha, it requires less endodontic cement (6) and it requires less time to be performed (10).

Because the root canal filling technique may interfere with the quality of the root canal filling, it is important to analyze the influence of the lateral condensation, vertical compaction and modified Tagger hybrid techniques on the penetration and bond strength of the cement in an epoxy resin-based sealer adhering to the root dentin.

\section{Material and Methods}

This study was submitted to and approved by the Research Ethics Committee of the Universidade de Ribeirão Preto (CAAE Registry No.: 15661713.2.0000.5498).

Forty roots of human maxillary central incisors were biomechanically prepared using the ProTaper system (Dentsply Maillefer, Ballaigues, Switzerland) up to the F5 instrument, which was operated by reducing contra-angle (Dabi Atlante, Ribeirão Preto, SP, Brazil) with continuous rotation ( $5 \mathrm{Nm}$ torque). The roots were randomly distributed into four groups $(n=10)$ according to the root canal filling technique: lateral condensation, vertical compaction, modified Tagger hybrid and single cone. All specimens were filled with AH Plus (Dentsply Maillefer), 0.1\% fluorescein (11) and gutta-percha.

\section{Lateral Condensation Technique}

The AH Plus was placed inside the root canal by a \#40 
lentulo drill, and the main cone of the F5 gutta-percha (Dentsply Maillefer; Petrópolis, RJ, Brazil) was inserted up to the working length. Next, with a \#25 digital spacer set (Dentsply Maillefer) adjacent to the main cone, was obtained for the insertion of accessory gutta-percha $F$ cones (Dentsply Maillefer; Petrópolis).

\section{Vertical Compaction Technique}

The specimens were filled as described in the lateral condensation technique and in the end, the vertical compaction technique was performed on the filling material with a heated No. 3 Paiva condenser (Duflex; SS White Artigos Dentários Ltda., Rio de Janeiro, RJ, Brazil).

\section{Modified Tagger Hybrid Technique}

Medium-sized thermo-plasticized gutta-percha cones were calibrated on a gauge and used as the main cone 1 $\mathrm{mm}$ short of the working length. Two $\mathrm{F}$ thermo-plasticized gutta-percha accessory cones were cemented and inserted into the root canal immediately after the removal of a \#25 digital spacer. Next, gutta-percha was thermo-plasticized by a \#60 McSpadden compactor (Dentsply Maillefer) mounted in contra-angle (Dabi Atlante; Ribeirão Preto, SP, Brazil) clockwise toward the apical third, with $1 \mathrm{~mm}$ wide pumping movements, keeping the instrument in contact with the gutta-percha cones at the entrance of the root canals.

\section{Single Cone Technique}

The sealer was placed inside the root canal with a \#40 drill. Next, an F5 gutta-percha cone was cemented up to the working length and excess gutta-percha was removed with a heated Hollenback $3 \mathrm{~S}$ carver (Duflex). After root canal filling, the excess material was removed from the mouth of the root canal with the heated Hollenback $3 \mathrm{~S}$ carver.

After three times the hardening time (480 $\mathrm{min}$ ) required for the AH Plus cement (11), the specimens were fixed on acrylic plates using hot glue (Hot Melt, Rhamos e Brito; São Paulo, SP, Brazil) and sectioned in 2-mm slices by a cutting machine (Isomet 1000; Buehler; Hong Kong, China) at $325 \mathrm{rpm}$ under refrigeration.

\section{Confocal Laser Scanning Microscopy (CLSM)}

The first slice of each third was analyzed in a Leica SEM inverted confocal microscope (Leica; Mannheim, Germany) in the epifluorescence mode. The images of the filled areas were acquired at absorption wavelengths and fluorescein emission wavelengths of $536 \mathrm{~nm}$ and $617 \mathrm{~nm}$, respectively.

The samples were analyzed $10 \mu \mathrm{m}$ below the surface at 500x magnification and images were obtained using a scanner with $241-\mu \mathrm{m}$ sections and at a resolution of $512 \times 512$ pixels. Images were acquired using the Leica Application Suite-Advanced Fluorescence software (Leica) and were imported into Image Tool version 3 (University of Texas Health Sciences Center, San Antonio, TX, USA) to calculate the circumference of the root canal wall. The root dentin where sealer penetration occurred was circumvented and measured to determine the percentage of sealer penetration.

\section{Push-Out Test}

After CLSM, the slices were subjected to the push-out test in a universal testing machine (Instron 4444; Instron Corporation; Canton, MA, USA) at $0.5 \mathrm{~mm} / \mathrm{min}$ speed. The test pieces were positioned in a stainless steel device so that the side of the root canal with the smallest diameter was turned upward and centered relative to the rod used to press the filling material, until it was moved from the test piece. Rods with $4 \mathrm{~mm}$ length and $1.0 \mathrm{~mm}$ diameter were used to remove the filling material from the cervical third; rods with $0.6 \mathrm{~mm}$ diameter were used to remove the filling material from the middle third, and rods with $0.4 \mathrm{~mm}$ diameter were used to remove the filling material from the apical third.

Data on the percentage of penetration (\%) of the $\mathrm{AH}$ Plus into the root dentin and on bond strength (MPa) were used in the analysis of variance and a complementary Tukey test, with a significance level of $5 \%(\alpha=0.05)$. For analyzes, the Statistical Package for the Social Sciences (SPSS) software was used (SPSS, Inc., Chicago, IL., USA).

After the push-out test, the samples were analyzed under a stereoscopic magnifying glass (Leica Microsystem LTD; Wetzlar, Germany) with 40x magnification and were classified according to the type of failure as follows: adhesive (when the root canal walls were completely free from the filling material), cohesive (when the root canal walls were completely covered by the filling material) and mixed (when the root canal walls were partially covered by the filling material).

\section{Scanning Electron Microscopy}

The second slice of each third was used in the analysis of the dentin/filling interface by scanning electron microscopy. The samples were prepared for this analysis using the methodology recommended by Carneiro et al. (4). Analyses were performed in a 5-kV JSM 5410 scanning electron microscope (JEOL Ltd; Tokyo, Japan) by three double-blinded examiners with experience in the area. The specimens were analyzed in a panoramic view (15x) to locate the representative areas and then in 500x magnifications.

\section{Results CLSM}

Qualitative analysis of the histotomographies (Fig. 1) of the experimental groups revealed AH Plus tags in 
dentinal tubules, which were visualized in green due to $0.1 \%$ fluorescein. Overall, the qualitative analysis of the lateral condensation, vertical compaction and modified Tagger hybrid techniques revealed greater penetration of the sealer into dentinal tubules than that of the single cone technique. In the quantitative analysis (\%), Tukey's test showed that the single cone technique had the lowest mean values (Table 1$)$. These results differed significantly $(p<0.05)$ from those of the other techniques, which produced similar values $(p>0.05)$. Tukey's test revealed that the cervical third $(95.36 \pm 7.24)$ and middle third $(88.67 \pm 14.62)$ had significantly higher values $(p<0.05)$ than those of the apical third $(75.98 \pm 19.81)$.

\section{Bond Strength}

Lateral condensation and vertical compaction techniques had the highest values and were statistically similar ( $p>0.05$ ) (Table 1). The modified Tagger hybrid technique had intermediate values that significantly differed $(p<0.05)$ from those of the single cone technique, which had the lowest values. The cervical third $(2.65 \pm 1.40)$ had the highest bond strength values and significantly differed from the middle third $(2.35 \pm 1.20)$ and apical third (2.23 \pm 1.21$)$. The analysis of the type of failure (Table 2) applied after the push-out test demonstrated a predominance of cohesive failures in the cervical third and mixed failures in the middle and apical thirds in the

Table 1. Tukey's test for the percentage of the penetration (\%) of the root canal filling mass into dentinal tubules and bond strength for the intraradicular dentin after the different root canal filling techniques were applied.

\begin{tabular}{lcc}
\hline $\begin{array}{l}\text { Root canal filling } \\
\text { techniques }\end{array}$ & $\begin{array}{c}\text { Penetration } \\
\text { depth }(\%)\end{array}$ & $\begin{array}{c}\text { Bond Strength } \\
(\mathrm{MPa})\end{array}$ \\
\hline Lateral condensation & $89.18 \pm 10.91 \mathrm{~A}$ & $3.42 \pm 0.54^{*}$ \\
Vertical compaction & $91.77 \pm 13.51 \mathrm{~A}$ & $3.47 \pm 0.53^{*}$ \\
Modified Tagger's hybrid & $87.53 \pm 15.42 \mathrm{~A}$ & $2.19 \pm 0.41^{* *}$ \\
Single Cone & $78.19 \pm 22.46 \mathrm{~B}$ & $0.54 \pm 0.21^{* * *}$ \\
\hline
\end{tabular}

Different letters and symbols indicate statistically significant differences $(\mathrm{p}<0.05)$. Critical values: penetration (9.5778) and bond strength (0.2690).

\begin{tabular}{|c|c|c|c|c|c|c|c|c|c|c|c|c|}
\hline \multirow{2}{*}{$\begin{array}{l}\text { Type of } \\
\text { failure }\end{array}$} & \multicolumn{3}{|c|}{ Lateral condensation } & \multicolumn{3}{|c|}{ Vertical compaction } & \multicolumn{3}{|c|}{ Modified Tagger's hybrid } & \multicolumn{3}{|c|}{ Single cone technique } \\
\hline & CT & MT & AT & CT & MT & $\mathrm{AT}$ & $\mathrm{CT}$ & MT & $\mathrm{AT}$ & $\mathrm{CT}$ & MT & AT \\
\hline Adhesive & 0 & 20 & 40 & 0 & 0 & 40 & 20 & 20 & 40 & 40 & 60 & 80 \\
\hline Mixed & 40 & 60 & 50 & 40 & 70 & 50 & 60 & 50 & 60 & 60 & 40 & 20 \\
\hline Cohesive & 60 & 20 & 10 & 60 & 30 & 10 & 20 & 30 & 0 & 0 & 0 & 0 \\
\hline
\end{tabular}

CT: Cervical third; MT: Middle third; AT: Apical third.
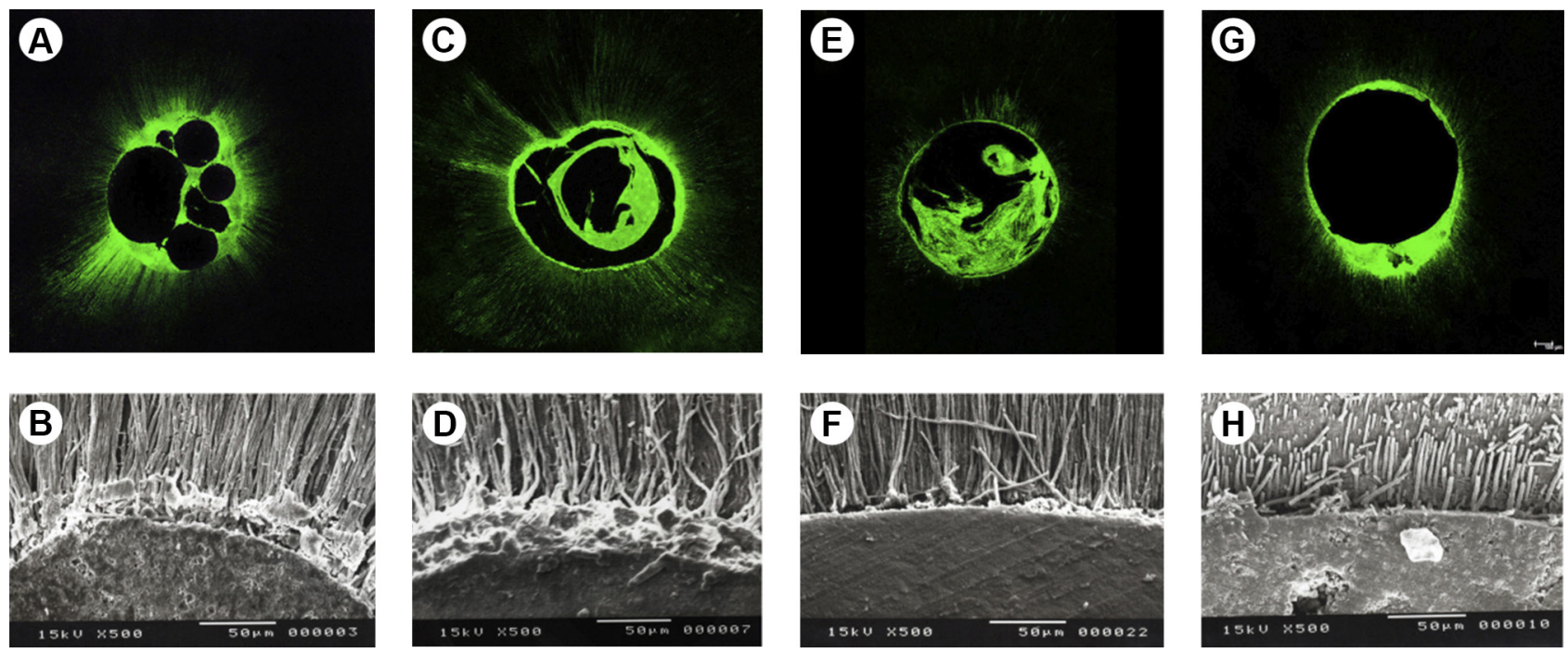

Figure 1. CLSM micrographs and SEM micrographs representing the root canal filling techniques of lateral condensation (A, B), vertical compaction (C, D), modified Tagger's hybrid (E, F) and single cone (G, H). 
specimens filled by the lateral condensation and vertical compaction techniques. In the modified Tagger hybrid technique prevailed the mixed failures in all thirds. When the single cone technique was used, mixed and adhesive failures were the most common.

\section{Scanning Electron Microscopy}

In the qualitative analysis based on SEM, thin, short tags were found in smaller quantities in the single cone technique. Meanwhile, in the lateral condensation, vertical compaction and modified Tagger hybrid techniques, the tags were longer, larger and more numerous.

\section{Discussion}

This study evaluated the impact of the lateral condensation, vertical compaction, modified Tagger hybrid and single cone root canal filling techniques on penetration to the root dentin and bond strength to the root canal wall when the AH Plus sealer was used.

In this study, the single cone technique resulted in low penetration and bond strength, with a thick sealer layer between the gutta-percha cone and root canal wall, as observed in the histotomographies. This may have resulted in mixed and adhesive failures at the bonding interface, even when the F5 gutta-percha cone that corresponded to the F5 instrument was used. According to Gordon et al. (6), the gutta-percha cone with taper corresponding to the biomechanical preparation instrument provides adequate filling of the root canal with a greater gutta-percha volume and a thin filling sealer layer. However, Chesler et al. (12) argued that the rotating instruments and gutta-percha cones of the ProTaper Universal system are not equivalent to the taper, which may have influenced the dentin/filling interface and therefore, the extent of penetration and bond strength results found in the present study.

The lateral condensation and vertical compaction techniques had the highest penetration and bond strength values. According to Hatton et al. (13), when the root canal is filled, gutta-percha cones exert pressure against the walls leading to increased interaction between the sealer and the root dentin. Following this reasoning, a digital spacer and accessory gutta-percha cones were used in the techniques applied in the current study. This choice may have resulted in a combination of forces in the lateral direction and probably favored penetration and bond strength. This result was confirmed in the qualitative analyses and the types of failures (cohesive and mixed) observed with these techniques. In addition, Carneiro et al. (4) reported that compared to the modified Tagger hybrid technique, the lateral condensation technique produced a denser and more compact obturating mass and a greater volume of gutta-percha than that of the sealer.
The histotomographies and electromicrographs (SEM) of the modified Tagger Hybrid technique revealed high penetration of sealer inside dentinal tubules, which may be due to the McSpadden compactor. This compactor tends to compress the filling material against the walls at high pressure, which results in greater filling of lateral canals and anatomical irregularities with gutta-percha and sealer $(9,14-16)$. This process may have favored the penetration of the sealer into the dentin. Heating the filling material provides a volumetric increase in gutta-percha and a lower percentage of empty spaces than the lateral condensation technique (17). However, this technique resulted in intermediate bond strength to the root canal wall, which can be explained by the fact that heating altered the chemical (18) and morphological (19) composition of the AH Plus sealer and accelerated its polymerization (20), consequently decreasing its chemical interaction time with the dentin. Carneiro et al. (4) reported that thermoplastic and compacted gutta-percha tends to mix with the sealer to form a non-uniform mass; as it cools, it contracts and tractions the filling sealer, which cools more quickly and forms gaps and negatively affects the bond strength and type of the observed mixed failure.

Regardless of the evaluated root canal filling technique, greater penetration and bond strength were observed for the cervical and middle thirds than for the apical third. These findings have also been reported by Ordinola-Zapata et al. (21), Chandra et al. (22) and De-Deus et al. (8), and could be explained by the quantity and diameter of the dentinal tubules of the root canal wall (23). Babb et al. (24) suggested that variations in tubular density throughout the canal are insufficient to alter the adhesiveness of the endodontic sealer. However, similar to the present study, Carneiro et al. (4) found higher bond strength of the filling material in the cervical third, regardless of the root canal filling technique. Further studies are needed to clarify the pressures exerted on the root canal wall at the time of root canal filling.

\section{Resumo}

Avaliou-se a influência da técnica obturadora na penetração do cimento $\mathrm{AH}$ Plus nos túbulos dentinários, por meio de microscopia confocal de varredura a laser (MCVL), e o impacto na resistência de união do material obturador à dentina, por meio do teste de push out. Raizes de incisivos centrais superiores $(n=40)$ foram preparadas com ProTaper Universal e distribuidas em 4 grupos: Condensação lateral, Compactação vertical, Hibrida de Tagger Modificada e Cone único. Após obturação com guta percha e AH Plus acrescido de fluoresceina $0,01 \%$, as raizes foram seccionadas em slices de 2,0 $\mathrm{mm}$. 0 primeiro slice de cada terço foi submetido à $M C V L$ e, posteriormente, ao teste de push out. 0 segundo slice foi analisado em MEV. ANOVA demonstrou diferença estatisticamente significante para as técnicas obturadoras e terços radiculares $(p<0,05)$. Para o percentual de penetração, Tukey evidenciou que compactação vertical $(91,77 \pm 13,51)$, Condensação lateral $(89,18 \pm 10,91)$ e Híbrida de Tagger Modificada $(87,53 \pm 15,42)$ apresentaram os maiores valores, 
estatisticamente diferentes $(p<0,05)$ da Cone único $(78,19 \pm 22,46)$. $\mathrm{Na}$ resistência de união $(\mathrm{MPa})$, Condensação lateral $(3,42 \pm 0,54)$ e Compactação vertical $(3,47 \pm 0,53)$ obtiveram os maiores valores, diferentes $(\mathrm{p}<0,05)$ da Hibrida de Tagger Modificada $(2,19 \pm 0,41)$ e da Cone único $(0,54 \pm 0,21)$, que teve os menores valores. Concluiu-se que as técnicas obturadoras Condensação lateral, Compactação vertical e Hibrida de Tagger Modificada propiciaram maior penetração e resistência de união à dentina intrarradicular.

\section{References}

1. Vilanova WV, Carvalho-Junior JR, Alfredo E, Sousa-Neto MD, SilvaSousa YT. Effect of intracanal irrigants on the bond strength of epoxy resin-based and methacrylate resin-based sealers to root canal walls. Int Endod J 2012;45:42-48.

2. Fuzinatto RN, Farina $A P$, Souza MA, Miyagaki DC, Randi Ferraz CC, Cecchin D. Effects of an endodontic auxiliary chemical substance on the bond strength of two methacrylate-based endodontic sealers to dentin. Microsc Res Tech 2017;80:627-633.

3. Mamootil K, Messer HH. Penetration of dentinal tubules by endodontic sealer cements in extracted teeth and in vivo. Int Endod J 2007;40:873881.

4. Carneiro SM, Sousa-Neto MD, Rached-Junior FA, Miranda CE, Silva SR, Silva-Sousa YT. Push-out strength of root fillings with or without thermomechanical compaction. Int Endod J 2012;45:821-828.

5. Kumar NSM, Prabu PS, Prabu N, Rathinasamy S. Sealing ability of lateral condensation, thermoplasticized gutta-percha and flowable gutta-percha obturation techniques: A comparative in vitro study. J Pharm Bioallied Sci 2012;4:131-135.

6. Gordon MPJ, Love RM, Chandler NP. An evaluation of 0.06 tapered gutta-percha cones for filling of 0.06 taper prepared curved root canals. Int Endod J 2005;38:87-96.

7. Leduc J, Fishelberg G. Endodontic obturation: a review. Gen Dent 2003;51:232-233.

8. De-Deus G, Brandão MC, Leal F, Reis C, Souza EM, Luna AS, et al.. Lack of correlation between sealer penetration into dentinal tubules and sealability in nonbonded root fillings. Int Endod J 2012;45:642-651.

9. Schilder H. Filling root canal in three dimensions. Dent Clin North Am 1967; $11: 723-744$.

10. Schäfer E, Koster M, Burklein S. Percentage of gutta-percha-filled areas in canals intrumented with nickel-titanium systems and obturated with matching single cones. J Endod 2013;39:924-928.

11. Flores DS, Rached-Junior FJ, Versiani MA, Guedes DF, Sousa-Neto MD, Pécora JD. Evaluation of physico-chemical properties of four root canal sealers. Int Endod J 2011;44:126-135.

12. Chesler MB, Tordik PA, Imamura GM, Goodell GG. Intra-manufacturer diameter and taper variability of rotary instruments and their corresponding gutta-percha cones. J Endod 2013;39:538-541.

13. Hatton JF, Ferrillo PJ, Wagner G, Stewart P. The effect of condensation pressure on the apical seal. J Endod 1988;14:305-308.

14. Carvalho-Sousa $A B$, Almeida-Gomes $F$, Carvalho PR, Maníglia-Ferreira C, Gurgel-Filho ED, Albuquerque DS. Filling lateral canals: evaluation of different filling techniques. Eur J Dent 2010;4:251-256.

15. Schilder $\mathrm{H}$. Filling root canals in three dimensions. J Endod 2006;32:281-290.

16. Brosco VH, Bernardineli N, Torres SA, Consolaro A, Bramante C, Moraes IG, Garcia RB. Bacterial leakage in root canals obturated by different techniques. Part 1: Microbiologic evaluation. Oral Sug Oral Med Oral Path Oral Radiol and Endod 2003;105:48-53.

17. Keles A, Ahmetoglu F, Uzun I. Quality of different gutta-percha techniques when filling experimental internal resorptive cavities: a micro-computed tomography study. Aust Endod J 2014;40:131-135.

18. Viapiana R, Baluci CA, Tanomaru-Filho M, Camilleri J. Investigation of chemical changes in sealers during application of the warm vertical compaction technique. Int Endod J 2015;48:16-27.

19. Viapiana R, Guerreiro-Tanomaru JM, Tanomaru-Filho M, Camilleri J. Investigation of the effect of sealer use on the heat generated at the external root surface during root canal obturation using warm vertical compaction technique with System B heat source. J Endod 2014;40:555-561.

20. Kaya BU, Keçeci AD, Orhan H, Belli S. Micropush-out bond strengths of gutta-percha versus thermoplastic synthetic polymer-based systems an ex vivo study. Int Endod J 2008;41:211-218.

21. Ordinola-Zapata $R$, Bramante CM, Graeff MSZ, del Carpio Perochena A, Vivan RR, Camargo EJ, et al.. Depth and percentage of penetration of endodontic sealer into dentinal tubules after root canal obturation using lateral compaction technique: A confocal laser scanning microscopy study. Oral Surg Oral Med Oral Pathol Oral Radiol and Endod 2009;108:450-457.

22. Chandra SS, Shankar $P$, Indira R. Depth of penetration of four resin sealers into radicular dentinal tubules: A confocal microscopic study. J Endod 2012;38:1412-1416.

23. Tao L, Pashley DH. Shear bond strengths to dentin: effects of surface treatments, depth and position. Dent Mater 1988;4:371-378.

24. Babb BR, Loushine RJ, Bryan TE, Ames JM, Causey MS, Kim J, et al.. Bonding of self-adhesive (self-etching) root canal sealers to radicular dentin. J Endod 2009;35:578-82.

Received November 11, 2016 Accepted June 6, 2017 